\title{
ADSORPTION OF CATIONIC AND ANIONIC DYES FROM AQUEOUS SOLUTION USING SUNFLOWER HUSK
}

\author{
Huda A. Jaber ${ }^{1}$, Marwa F. Abdul Jabbar ${ }^{1,} \bowtie$
}

https://doi.org/10.23939/chcht15.04.567

\begin{abstract}
The current study deals with the removal of cationic dye (brilliant green) and anionic dye (methyl orange) from wastewater by using sunflower husk as an adsorbent. The operation takes place batch wise by applying several concentrations of the dye solution with various adsorbent amounts, at a range of initial $\mathrm{PH}$ values and particle sizes at varying contact time intervals. The percent of dye removed for two dyes increased with increasing time and adsorbent dose and decreased with increasing the dye concentration and particle size. The equilibrium time differed according to conditions used. The optimum removal for brilliant green dye was $98 \%$, which was achieved at $50 \mathrm{ppm}$ dye concentration, $2 \mathrm{~g} \backslash \mathrm{l}$ adsorbent dose, $75 \mu \mathrm{m}$ particles size and $\mathrm{pH} 7$ at contact time of $1 \mathrm{~h}$, compared with low removal for methyl orange that reached $54 \%$ under optimum conditions (dye concentration 10 ppm, adsorbent dose $4 \mathrm{~g} / 1, \mathrm{pH} 3$ at the same particles size and time). Kinetic studies were conducted and revealed that the adsorption was well defined by pseudo-second order model and could be described by the Langmuir isotherm.
\end{abstract}

Keywords: adsorption, sunflower husk, methyl orange, brilliant green, basic dyes, acidic dyes.

\section{Introduction}

The textile industry consumes huge amounts of water in wet processing operations, thus inducing essential quantities of wastewater, including large amounts of heavy metals, organic pollutants and coloring materials. Among them, the colored dyes materials cause numerous problems [1].

Dyes are main components usually used in different industries such as leather, textile, paper and plastic production [2]. These industries consume large amounts of water and result in extensive volumes of wastewater from various processes in the dyeing and

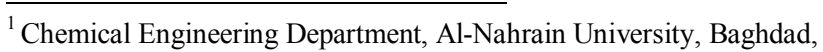
Iraq

凶marwa84_2007@yahoo.com

(c) Jaber H., Abdul Jabbar M., 2021
}

finishing steps. Therefore, the existence of small amounts of dyes in water (less than $1 \mathrm{mg} / \mathrm{dm}^{3}$ for some dyes) is extremely apparent and unfavorable [3]. Color hinders the accurate entry of sunlight into water bodies, obstructing photosynthesis, preventing the growth of aquatic biota and influencing the solubility of gases within the water bodies. Dyes have been represented universally as poisonous since they cause skin, lung and respiratory problems [4].

Dyes exist in many structural forms, including anionic (reactive and acid dye), cationic (basic dyes) and nonionic dyes (vat dyes and dispersed dyes) [5]. According to dye classifications, brilliant green and methyl orange are classified as cationic and anionic dyes, which need disposal from wastewater. They are widely used in textile dyeing and paper printing and are seemed toxic for humans and animals because they harm the eyes, and their contact with skin results in irritation with pain and redness. Therefore, the dye removal is of great significance [6].

Different treatment processes have been used for the dye removal, such as adsorption [7], reverse osmosis [8], solvent extraction [9], chemical precipitation [10], ion exchange [11], ozonation [12], coagulation-flocculation and membrane process [7]. Among these methods, adsorption is the most efficient technique for elimination of organic components from the aqueous solution because of its easy design, susceptibility to noxious materials and simplicity of operation [13]. But its utilization is finite due to the adsorbents high cost and persistent problems of the regeneration. Therefore, consideration for organic pollutant removal employing substitutional low cost adsorbents is presently increasing by many researchers [14].

Various agricultural biomasses like peanut hulls [15], palm kernel fiber [16], sugarcane dust [17], wheat straw and apple pomace [18], banana peel and orange peel [19], citrullus lanatus peel [20], waste tea leaf [21], tree fern [22], Annona squamosal seed [23], coffee husk [24] and sawdust [25] have been already studied for the removal of various kinds of dyes. The employment of plant residues for the wastewater treatment has the following advantages: (i) plant residues are cellulosic compounds which have a natural capability to uptake waste chemicals such as dyes from water by means of the 
coulombic interaction; (ii) plant residues are agricultural wastes obtainable in large quantities at low or no cost; (iii) wastes elimination is a proper environmental issue in the countries that have extended agricultural activities [26].

The present study is an attempt to eliminate methyl orange (MO) and brilliant green (BG) from synthetic wastewater by an adsorption process using sunflower husk, which is an agricultural waste, as an adsorbent. The influences of different parameters such as initial dye concentration, adsorbent dosage, solution $\mathrm{pH}$, particles size and kinetics were studied.

\section{Experimental}

\subsection{Materials and Methods}

In this study methyl orange (acid dye) and brilliant green (basic dye), purchased from Sigma-Aldrich, were used as the model adsorbates. The structure of these dyes and their physical properties are shown in Table 1. Stock solution with $250 \mathrm{ppm}$ dye concentration was provided by dissolving $0.25 \mathrm{~g}$ of dye in 1 liter of distilled water, and other concentrations were prepared by dilution of the stock solution.

Sunflower husk was used as an adsorbent for elimination of dyes from water. It was locally obtained from sunflower seeds, washed by water to remove any dirt and dried in the oven at $353 \mathrm{~K}$ for $24 \mathrm{~h}$. The dried materials were ground and sieved to achieve sizes of particles ranging within $75-600 \mu \mathrm{m}$. No physical or chemical treatments were employed before adsorption experiments.

The chemical composition of the sunflower husk was: $29.3 \%$ of lignin, $31.9 \%$ of cellulose and $27.2 \%$ of pentosane [27].

Sulfuric acid and potassium hydroxide were used to adjust the acidity and basicity of the solution.

Table 1

Physical properties of dyes

\begin{tabular}{|c|c|c|}
\hline \multirow{2}{*}{ Properties } & Brilliant green & Dye \\
\cline { 2 - 4 } & 482.639 & 327.33 \\
\hline Molecular weight, g/mol & Methyl orange \\
\hline Chemical formula & $\mathrm{C}_{27} \mathrm{H}_{33} \mathrm{~N}_{2} \mathrm{HO}_{4} \mathrm{~S}$ & \\
\hline Molubility in water at $293 \mathrm{~K}$ & $100 \mathrm{~g} / 1$ & $\mathrm{C}_{14} \mathrm{H}_{14} \mathrm{~N}_{3} \mathrm{NaO}_{3} \mathrm{~S}$ \\
\hline
\end{tabular}

\subsection{Adsorption Process}

The experimental works were performed by addition of specific amounts of adsorbent into $200 \mathrm{ml}$ volumetric flasks having particular volumes $(150 \mathrm{ml})$ of various initial dye concentrations: $25-100 \mathrm{ppm}$ for brilliant green and 10-50 ppm for methyl orange. The flasks were placed in a shaker (type KOTTERMANN 4010, Germany) and agitated for $60 \mathrm{~min}$. Then the samples were withdrawn at different intervals to measure the dye concentration at different times using UV-visible spectrophotometer (Jenway model 6800) at maximum wavelengths of $625 \mathrm{~nm}$ for brilliant green and $470 \mathrm{~nm}$ for methyl orange. The percentage of dye removal can be calculated as follows:

$$
\% \text { removal }=\frac{C_{0}-C_{t}}{C_{0}} \cdot 100
$$

where $C_{0}$ and $C_{\mathrm{t}}$ are the dye concentrations at initial and any time, respectively, $\mathrm{mg} / \mathrm{l}$.

\subsection{Isotherm Studies}

Two isotherms such as Langmuir and Freundlich are usually employed for this study. The first isotherm depends on the hypothesis that adsorption occurs at particular homogeneous situations within the sorbent and as soon as a dye molecule takes up a site, no further adsorption happens at that site. Theoretically, the adsorbent has a restricted capability to adsorb the sorbate. Thus, a saturation value is accomplished over which no more adsorption happens. The monolayer capability can be represented by the following formula [28]:

$$
q_{e}=\frac{q_{m} b C_{e}}{1+b C_{e}}
$$


Eq. (2) was rearranged to Eq. (3)

$$
\frac{C_{e}}{q_{e}}=\frac{1}{q_{m}^{b}}+\frac{1}{q_{m}} C_{e}
$$

where $C_{e}$ is the concentration of the adsorbate at equilibrium, $\mathrm{mg} / \mathrm{l} ; q_{e}$ is the quantity of the adsorbate adsorbed per adsorbent mass unit and calculated from Eq. (3a), $\mathrm{mg} / \mathrm{g} ; q_{m}$ and $b$ are the Langmuir constants, their value can be calculated graphically from intercept and slope of plotting $\left(C_{e} / q_{e}\right) v s . C_{e}$ [29].

$$
q_{e}=\frac{\left(C_{0}-C_{e}\right) V}{m}
$$

where $C_{0}$ and $C_{e}$ are the initial concentration of dye and equilibrium concentration, respectively, $\mathrm{mg} / \mathrm{l} ; \quad V$ is the dye solution volume, $1 ; m$ is the mass of adsorbent, $\mathrm{g}$.

The Freundlich isotherm is an empirical model that supposes heterogeneous adsorptive energies on the adsorbent surface. It is expressed by the following equation [30]:

$$
q_{e}=K_{f} C_{e}^{1 / n}
$$

This equation is linearized by taking logarithms as follows:

$$
\log q_{e}=\frac{1}{n} \log C_{e}+\log K_{f}
$$

where $K_{f}$ and $1 / n$ are empirical constants. They can be determined by plotting $\log q_{e} v s . \log C_{e}$, and the slope of the line is the value of $1 / n$, while $\log K_{f}$ is the $y$-intercept of line.

\subsection{Kinetics of Adsorption Process}

For analyzing the adsorption of dye onto sunflower husks, pseudo-first order, pseudo-second order and intraparticle diffusion kinetic models were applied to the best experimental data [31].

The pseudo-first order model is generally expressed as:

$$
q_{t}=q_{e}\left(1-e^{-k_{1} t}\right)
$$

where $q t$ and $q_{e}$ are the biosorption capacity of dye at time $t$ and the equilibrium, respectively, $\mathrm{mg} / \mathrm{g} ; q_{t}$ is calculated according to Eq. (6a); $k_{1}$ is the biosorption rate constant of the pseudo-first order model.

$$
q_{t}=C_{0}-C_{t}
$$

where $C_{t}$ is the remaining dye concentration at time $t$, $\mathrm{mg} / \mathrm{l}$.

The pseudo second-order model supposes that the adsorption follows a second-order mechanism and chemical adsorption, perhaps the rate limiting step, that includes covalent forces or valence forces between adsorbate and sorbent.

The rate of the pseudo-second order reaction is expressed by Eq. (7):

$$
\frac{t}{q_{t}}=\frac{1}{k_{2} q_{e}^{2}}+\frac{t}{q_{e}}
$$

where $k_{2}$ is the pseudo-second order rate constant, $\mathrm{g} / \mathrm{mg} \cdot \mathrm{min}$.

The intra-particle diffusion model presumes that adsorption is a multi-step process including transfer of adsorbate from the aqueous solution to the sites of the adsorbent (surface sorption) and diffusion into pores (intra-particle diffusion) and this model is expressed as Eq. (8)

$$
q_{t}=k_{p} t^{1 / 2}+C
$$

where $k_{p}$ is the intra-particle diffusion rate constant, $\mathrm{mg} / \mathrm{g} \cdot \mathrm{min}^{1 / 2}$; $C$ is a constant, $\mathrm{mg} / \mathrm{g}$.

\section{Results and Discussion}

\subsection{Effect of $\mathbf{p H}$}

The influence of $\mathrm{pH}$ on the removal of brilliant green dye by sunflower husks was considered by variations in the $\mathrm{pH}$ of dye solution (from $\mathrm{pH} 3$ to $\mathrm{pH} 11$ ) at the initial dye concentration of $100 \mathrm{ppm}$, particles size of $75 \mu \mathrm{m}$ and sunflower husk amount of $2 \mathrm{~g} / \mathrm{l}$. The dye removal percentages $v s$. different $\mathrm{pH}$ values are plotted in Fig. 1.

The results indicate that the dye removal increases with increasing initial $\mathrm{pH}$ of the dye solution from 3 to 7 and decreases at $\mathrm{pH} 11$. It was $24 \%$ for an acidic medium, while maximum removal occurs at $\mathrm{pH} 7$, which was $80 \%$ after $50 \mathrm{~min}$, and as the $\mathrm{pH}$ value increases to 11 , the removal efficiency decreases to $66 \%$.

At lower $\mathrm{pH}$ values, the concentrations of $\mathrm{H}^{+}$are high and they contend with dye cations for unoccupied adsorption sites, leading to the decrease in the dye uptake. Increasing the $\mathrm{pH}$ value, the surface of adsorbent is negatively charged and encourages uptake of cationic dye because of increasing electrostatic force of attraction. For a higher value ( $\mathrm{pH}$ 11) the uptake level decreases due to the formation of a soluble hydroxyl complex between the adsorbent and the dye. This behavior agrees with Dakhil [32], who found the maximum removal of methylene blue by spent tea leaves at $\mathrm{pH} 7$ and less removal for acidic and basic solutions.

The effect of $\mathrm{pH}$ on the removal of methyl orange dye was also studied (Fig. 2). Low removal rates were obtained for natural and basic environments while for acid systems a higher removal percent $(26 \%)$ was obtained after 40 min. This means that the sunflower husk required activation or modification to be able to adsorb more methyl orange dye from the water. 


\subsection{Effect of Contact Time and Adsorbent Dosage}

The effect of time and adsorbent dosage on dye removal were investigated by varying the sunflower husk amount from 0.5 to $4 \mathrm{~g} / 1$ for brilliant green and from 4 to $15 \mathrm{~g} / 1$ for methyl orange at times ranging within 10 $60 \mathrm{~min}$, as illustrated in Figs. 3 and 4, respectively. The dye concentration was $50 \mathrm{ppm}$, particles size $75 \mu \mathrm{m}$ and optimum $\mathrm{pH}$ solution for each dye $\mathrm{pH} 7$ for brilliant green and $\mathrm{pH} 3$ for methyl orange). It was observed that the percentage of dye removal increased as time and sunflower husk dosage were increased.

It can be seen from Fig. 3 that the removal efficiency of brilliant green increased with increasing time for all adsorbent doses due to existence of free sites on the upper surface of the biosorbent and then began slowing with the gradual occupancy of these sites [3]. Equilibrium

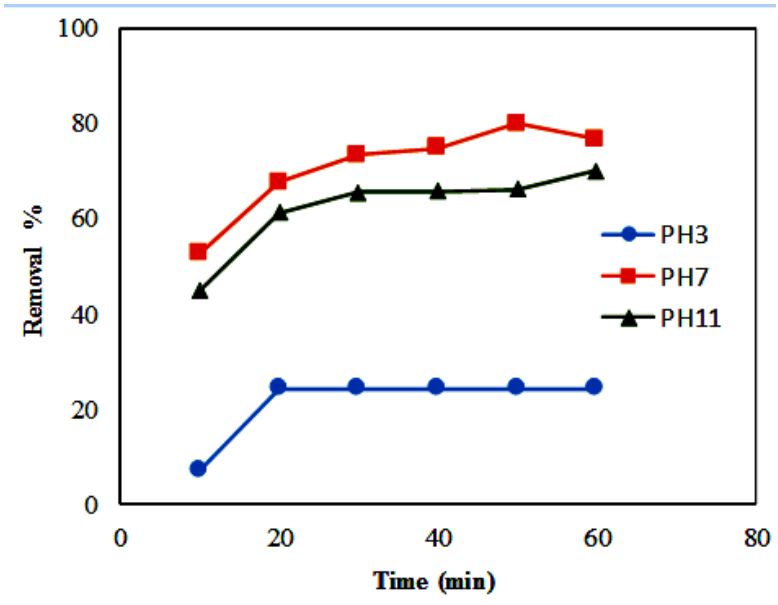

Fig. 1. Effect of $\mathrm{pH}$ on the brilliant green adsorption. Adsorbent dose is $2 \mathrm{~g} / 1$,dye concentration is $100 \mathrm{ppm}$ and particles size is $75 \mu \mathrm{m}$

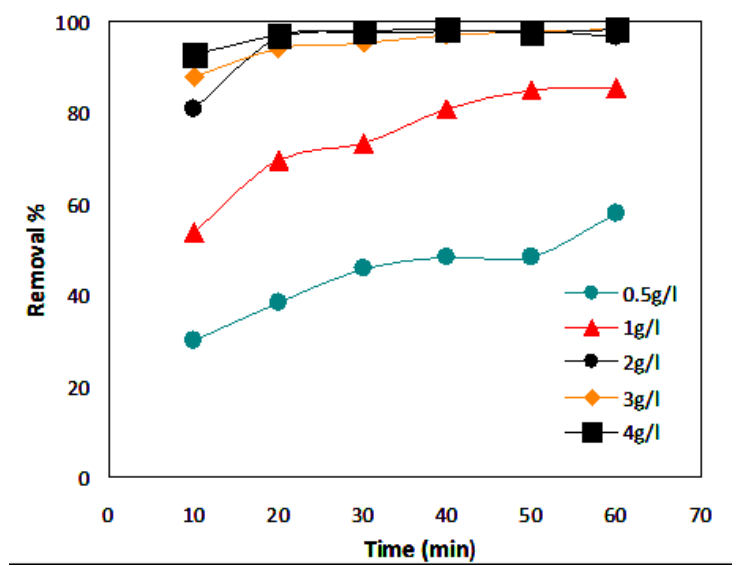

Fig. 3. Effect of sunflower husk dosage on the adsorption of brilliant green. Dye concentration is $50 \mathrm{ppm}$, particles size is $75 \mu \mathrm{m}, \mathrm{pH} 7$ time for each dosage differed depending on the amount of sunflower husks. It was $20 \mathrm{~min}$ for high amounts (2-4g/l), while for low dosage $(1 \mathrm{~g} / \mathrm{l})$ more time was needed to reach equilibrium (50 $\mathrm{min})$. Also, an increase in the biomass amount from 0.5 to $2 \mathrm{~g} / 1$ led to an increase in the removal efficiency from 58 to $96 \%$, after $60 \mathrm{~min}$. This is due to the increase in the surface area of sunflower husk and availability of more adsorption sites, consequently making penetration of the dye to the sorption sites [33] easier. Further increases of adsorbent to 3-4 g/l showed little difference for removal efficiency; therefore, it is not economical to increase adsorbent doses greater than $2 \mathrm{~g} / \mathrm{l}$.

A similar behavior was observed for methyl orange (Fig. 4). Although the amount of sunflower husk was higher than that used for brilliant green, a lower value of removal efficiency is observed. The maximum removal efficiency was $51 \%$ at adsorbent amount of $15 \mathrm{~g} / 1$ (cf. with $98 \%$ at adsorbent amount of $2 \mathrm{~g} / 1$ for brilliant green).

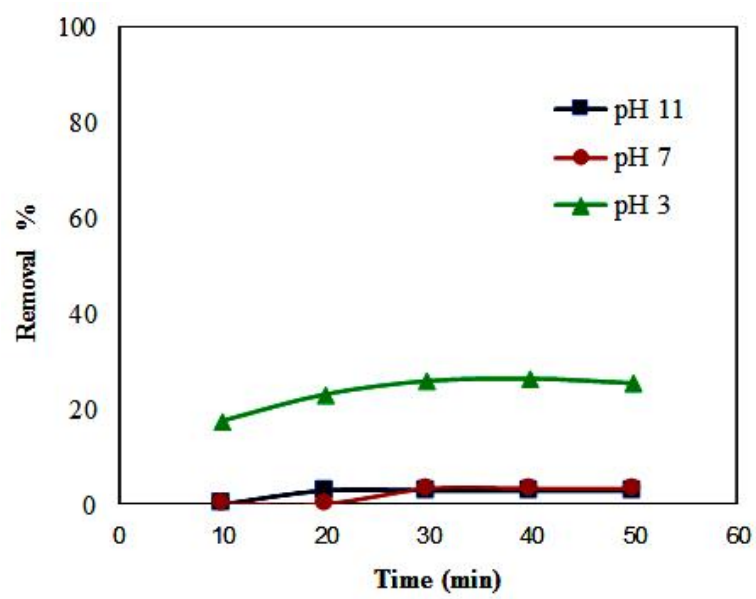

Fig. 2. Effect of $\mathrm{pH}$ on the methyl orange adsorption. Adsorbent dose is $4 \mathrm{~g} / 1$,dye concentration is $50 \mathrm{ppm}$ and particles size is $75 \mu \mathrm{m}$

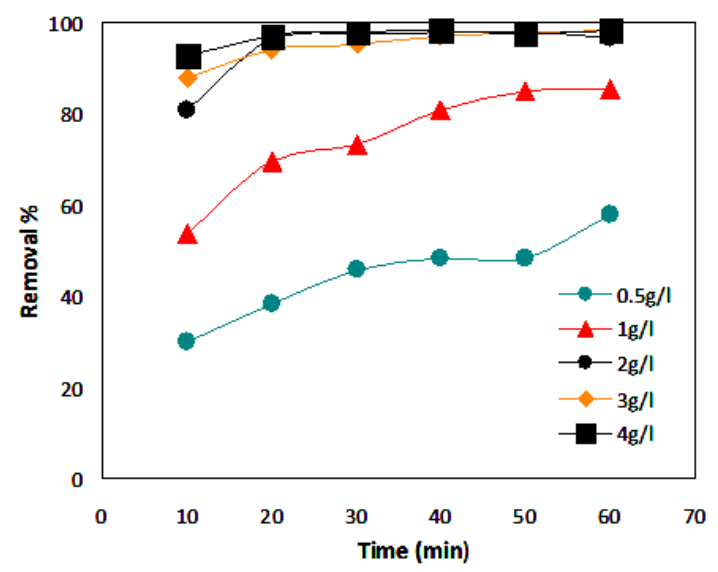

Fig. 4. Effect of sunflower husk dosage on the adsorption of methyl orange. Dye concentration is $50 \mathrm{ppm}$, particles size is $75 \mu \mathrm{m}, \mathrm{pH} 3$ 


\subsection{Effect of Adsorbate Concentration}

The effect of adsorbate concentration on the dye adsorption is illustrated in Fig. 5 and 6 for brilliant green and methyl orange, respectively.

As the concentration of dye increased from 25 to100 ppm (Fig. 5), the dye adsorbed percentage decreases from 98 to $77 \%$ after $60 \mathrm{~min}$. The result denotes that the removal efficiency depends on the initial concentration of dye. This phenomenon can be explained in terms of available active sites. At low concentrations of adsorbate, the ratio of active surface sites to total dye is high; hence the dye ions could interact with the adsorbent to occupy the active sites on

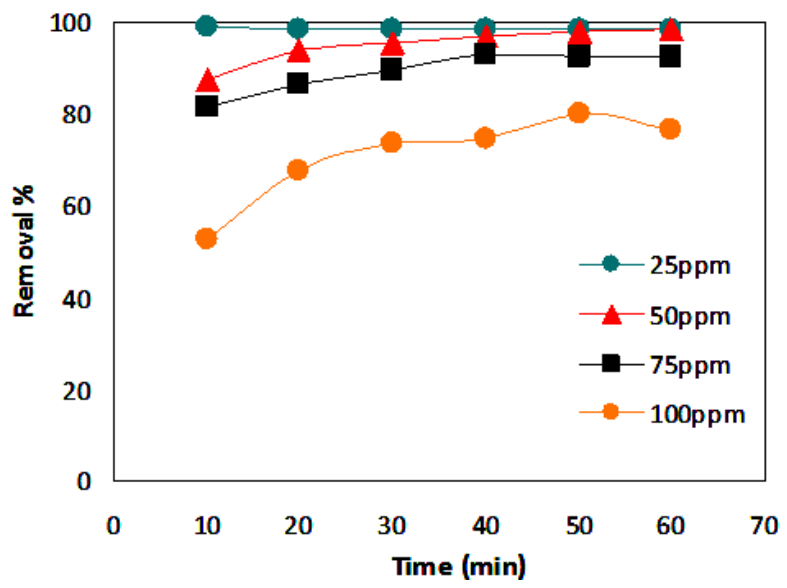

Fig. 5. Effect of adsorbate (brilliant green) concentration on the dye adsorption. Adsorbent dose is $2 \mathrm{~g} / \mathrm{l}$, particles size is $75 \mu \mathrm{m}, \mathrm{pH} 7$

\subsection{Effect of Particles Size}

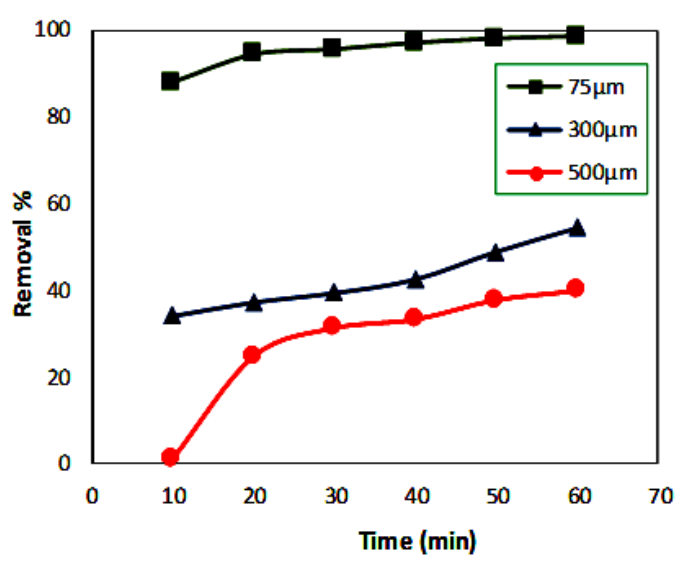

Fig. 7. Effect of particles size on the brilliant green adsorption. Adsorbent dose is $2 \mathrm{~g} / \mathrm{l}$, dye concentration is $50 \mathrm{ppm}, \mathrm{pH} 7$

The size of the adsorbent was varied to observe the influence of particles size on a removal efficiency. Since the adsorbent was not suitable for methyl orange removal, the sunflower husk surface and can be removed from the solution. But with the increase in adsorbate concentration, the number of active adsorption sites is not enough to contain dye ions, and this agrees with the literature data [34].

Fig. 6 represents how the methyl orange dye concentration affects the removal efficiency. After $50 \mathrm{~min}$, when the concentration decreased from 50 to $10 \mathrm{ppm}$, the removal increased from 24 to $54 \%$. Although the concentration of methyl orange was lower (10-50 ppm) than that of brilliant green (25-100 ppm), the sunflower husk was more effective for the removal of brilliant green. This means that it is not suitable for methyl orange removal.

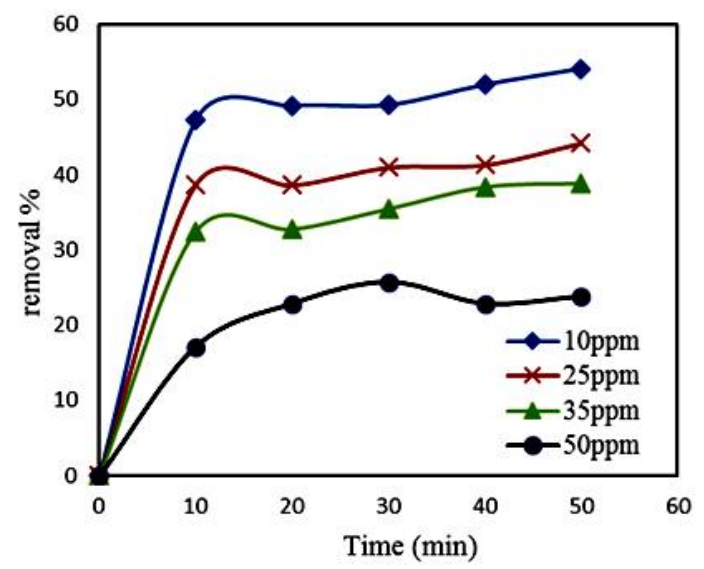

Fig. 6. Effect of adsorbate (methyl orange) concentration on the dye adsorption. Adsorbent dose is $4 \mathrm{~g} / \mathrm{l}$, particles size is $75 \mu \mathrm{m}, \mathrm{pH} 3$

the effect of its particles size was not studied. For brilliant green dye the experimental results are shown in Fig. 7 at the constant dye concentration of $50 \mathrm{ppm}$, adsorbent dose of $2 \mathrm{~g} / \mathrm{l}$ and $\mathrm{pH}$ 7. It was noted that the smaller size gave a higher removal efficiency: 98,54 and $40 \%$ for particles size of 75,300 and $500 \mu \mathrm{m}$, respectively, after contact time of $60 \mathrm{~min}$. The reason is that a great number of smaller particles accommodates the adsorption system with a greater surface area ready for dye removal [1].

\subsection{Comparison Between Cationic and Anionic Dyes}

The sunflower husk was used as an adsorbent for the uptake of two types of dyes, brilliant green as a cationic dye and methyl orange as an anionic dye. The results are shown in Fig. 8 at dye concentration of $50 \mathrm{ppm}$, adsorbent dose of $4 \mathrm{~g} / \mathrm{l}$, particles size of $75 \mu \mathrm{m}$ and $\mathrm{pH} 7$ for brilliant green and $\mathrm{pH} 3$ for methyl orange.

Cationic dyes are rapidly adsorbed on the sunflower husk. After $20 \mathrm{~min}$, nearly $97 \%$ of basic dyes 
can be removed from water, while for anionic species only about $23 \%$ were removed by the adsorbents. The greater attraction for the sunflower husk of cationic dyes than that of anionic dyes can be assigned to the cellulosic composition of the adsorbents.

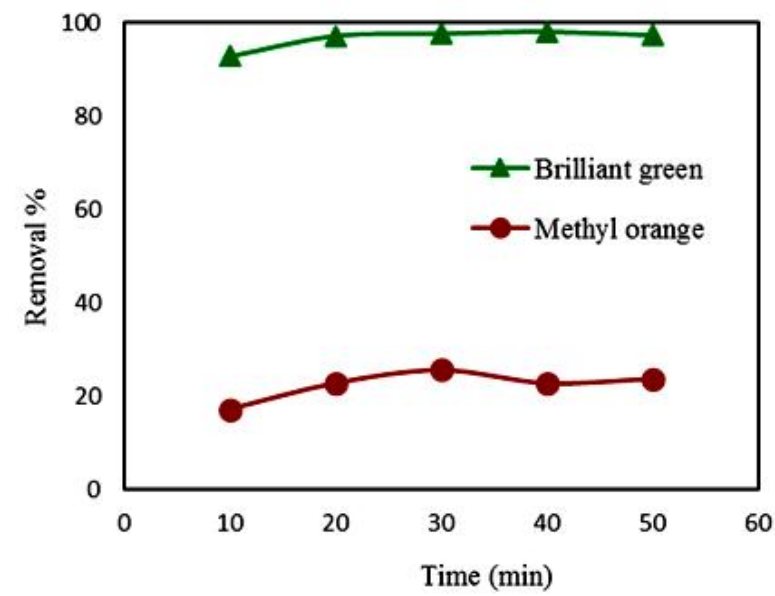

Fig. 8. Adsorption of methyl orange and brilliant green at concentration of $50 \mathrm{ppm}$. Adsorbent amount is $4 \mathrm{~g} / \mathrm{l}$, particles size is $75 \mu \mathrm{m}$
The coulombic forces between dye species and negatively charged cellulose in water are the main interactions which influence the dye adsorption on the sorbents. It is evident that higher adsorption rates are needed for the removal of anionic dye; the sunflower husk must be chemically modified with cationic groups.

This behavior agrees with Sun and $\mathrm{Xu}$ [26], who used sunflower stalks as an adsorbent for the removal of two types of cationic dyes and two types of anionic types. The higher removal percent was shown for cationic dyes (methylene blue), which was $80 \%$, compared with $10 \%$ for anionic dye (congo red).

\subsection{Adsorption Isotherm}

The adsorption isotherm and kinetics were calculated only for the best dye removal. Therefore, the experimental equilibrium adsorption data of brilliant green onto sunflower husks have been analyzed using Freundlich and Langmuir isotherms.

The parameters of Langmuir and Freundlich isotherms and the coefficients correlation $\left(R^{2}\right)$ of each isotherm were calculated by the linearized regression method and are listed in Table 2 and shown in Figs. 9 and 10 , respectively. Results specified that the adsorption is described well by the Langmuir isotherm model.

Table 2

Langmuir and Freundlich parameters

\begin{tabular}{|c|c|c|}
\hline & Parameter & Value \\
\hline Isotherm model & $q_{m}, \mathrm{mg} / \mathrm{g}$ & 61.728 \\
\hline \multirow{3}{*}{ Langmuir } & $b, \mathrm{l} / \mathrm{mg}$ & 0.711 \\
\cline { 2 - 3 } & $R^{2}$ & 0.9791 \\
\cline { 2 - 3 } & $K_{f}, \mathrm{mg} / \mathrm{g}$ & 26.867 \\
\hline \multirow{3}{*}{ Freundlich } & $n$ & 3.054 \\
\cline { 2 - 3 } & $R^{2}$ & 0.8699 \\
\cline { 2 - 3 } & & \\
\cline { 2 - 3 }
\end{tabular}

\subsection{Adsorption Kinetics}

Three kinetic models were used in this work: pseudo-first order, pseudo-second order, and intra-particle diffusion models. Figs. 11, 12 and 13 show the application of the kinetic models by plotting $\ln q_{t} v s . t,(t / q) v s . t$ and $q_{t}$ vs. $t^{1 / 2}$, respectively. To determine the degree of agreement for the kinetic model, the coefficients $R^{2}$ were determined. The highest $R^{2}$ specifies the applicability of the kinetics model.

The pseudo-second order model was more suitable to characterize the adsorption kinetic data for brilliant green, and all kinetics parameters are listed in Table 3.
Adsorption kinetic parameters

\begin{tabular}{|c|c|c|}
\hline Adsorption model & Parameter & Value \\
\hline \multirow{2}{*}{$\begin{array}{c}\text { The pseudo-first order } \\
\text { model }\end{array}$} & $K_{1}, \mathrm{~min}^{-1}$ & 0.0013 \\
\cline { 2 - 3 } & $q_{e}, \mathrm{mg} / \mathrm{g}$ & 45.6 \\
\cline { 2 - 3 } & $R^{2}$ & 0.922 \\
\hline \multirow{2}{*}{$\begin{array}{c}\text { The pseudo-second } \\
\text { order model }\end{array}$} & $K_{2}, \mathrm{~g} / \mathrm{mg} \cdot \mathrm{min}$ & 0.018 \\
\cline { 2 - 3 } & $q_{e}, \mathrm{mg} / \mathrm{g}$ & 50 \\
\cline { 2 - 3 } & $R^{2}$ & 0.9998 \\
\hline \multirow{3}{*}{ Diffusion model } & $K_{p}, \mathrm{mg} / \mathrm{g} \cdot \mathrm{min}^{1 / 2}$ & 0.6847 \\
\cline { 2 - 3 } & $C$ & 43.942 \\
\cline { 2 - 3 } & $R^{2}$ & 0.9634 \\
\hline
\end{tabular}




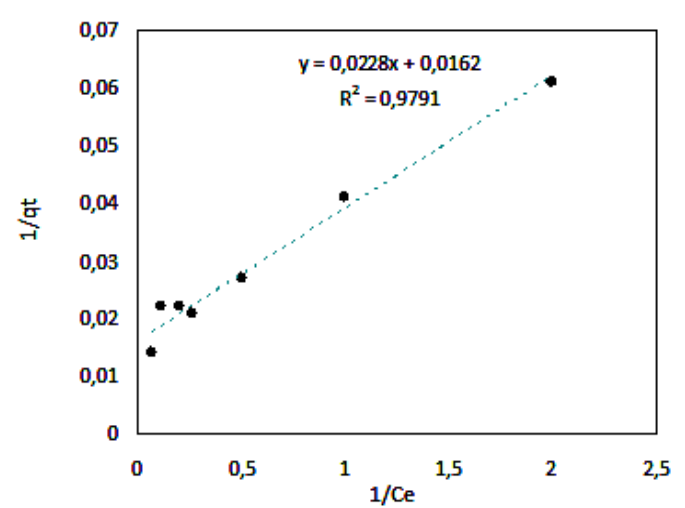

Fig. 9. Linearization of Langmuir model

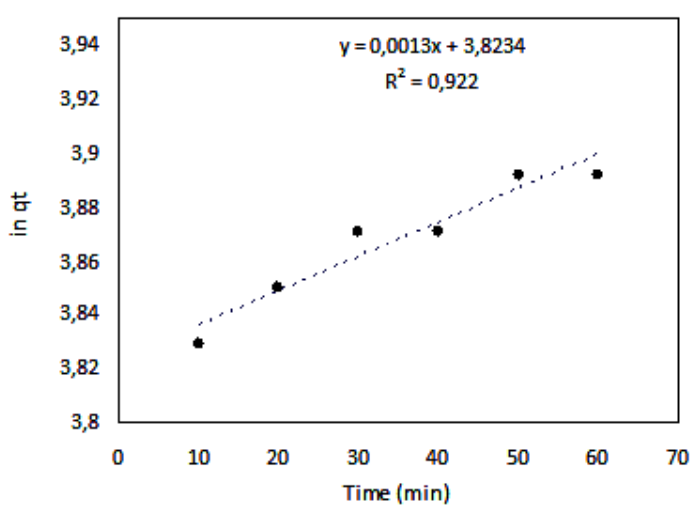

Fig. 11. Linearization of the pseudo-first order model

Fig. 13. Linearization of the intra-diffusion model

\section{Conclusions}

The adsorption process using sunflower husks ensures an excellent removal of brilliant green dye from water but is less effective for the removal of methyl orange dye, although the quantity of sunflower husks was high and the dye concentration was low. The best solution for brilliant green was neutral one $(\mathrm{pH} 7)$ since it gave high removal compared to acidic and alkaline media, while for

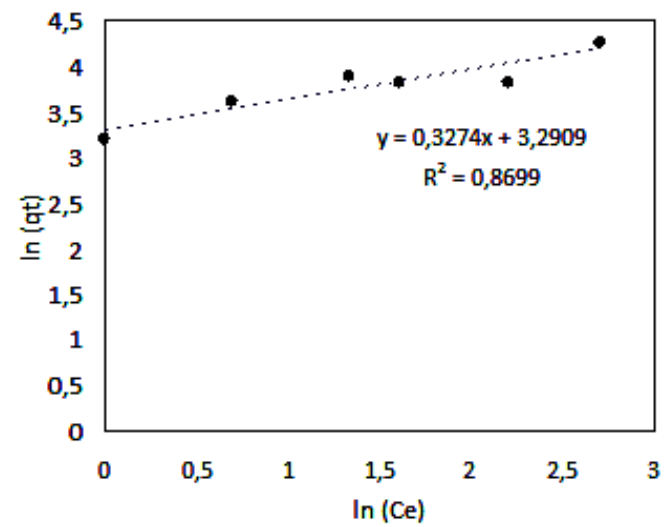

Fig. 10. Linearization of Freundlich model

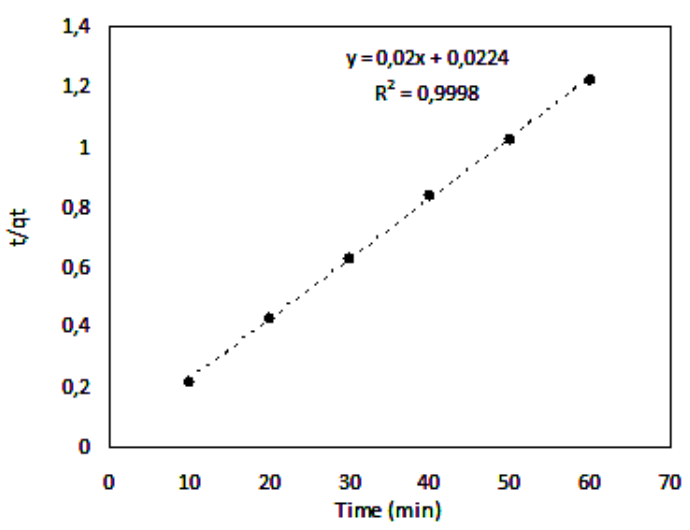

Fig. 12. Linearization of the pseudo-second order model

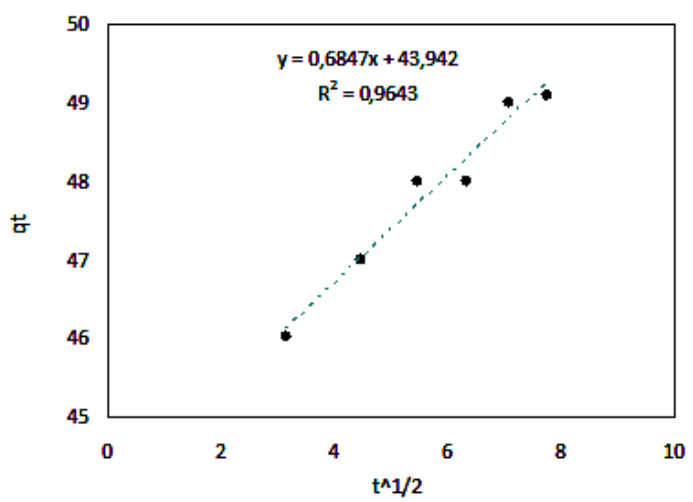

methyl orange the acidic medium was better than neutral and alkaline ones. The removal efficiency increases with the decrease in dye concentration and particles size. As the amount of adsorbents increases, the removal increases as a result of more available active sites. The optimum removal obtained from experiments was $98 \%$ using the sunflower husk, with adsorbent amount of $2 \mathrm{~g}$, brilliant green dye concentration $50 \mathrm{ppm}$, particles size $75 \mu \mathrm{m}$ and $\mathrm{pH}$ 7. The pseudo-second order model produced a better fit than other 
kinetic models and equilibrium experimental data were defined by a Langmuir isotherm model.

\section{References}

[1] Srisorrachatr S., Sriromreun P.: AJChE, 2013, 13, 25. https://doi.org/10.22146/ajche.49722

[2] Vieira A., Santana S., Bezerra C. et al.: Chem. Eng. J., 2011, 173, 334. https://doi.org/10.1016/j.cej.2011.07.043

[3] Oguntimein G.: Adv. Res. Text. Eng., 2016, 1, 1.

[4] Ali A., Kovo A., Adetunji S.: JEAS, 2017, 7, 95-107.

https://doi.org/10.4236/jeas.2017.72007

[5] Hashem A., Akasha R., Ghith A., Hussein D.: Energy Educ. Sci. Technol., 2007, 19, 69.

[6] Sun S., Wana W.: Biores. Technol., 2013, 140, 406.

https://doi.org/10.1016/j.biortech.2013.04.116

[7] Walker G., Hansen L., Hana J., Allen S.: Water Res., 2003, 37, 2081. https://doi.org/10.1016/S0043-1354(02)00540-7

[8] Shaban M., Abdulla H., Mahmoud L., Ahmed A.: J. Polym. Res., 2019, 26, 181. https://doi.org/10.1007/s10965-019-1831-4

[9] Yi S., Sun G., Dai F.: Text. Res. J., 2019, 88, 1641.

https://doi.org/10.1177/0040517517705631

[10] Tan B., Teng T., Omar A.: Water Res., 2000, 34, 597.

https://doi.org/10.1016/S0043-1354(99)00151-7

[11] Wawrzkiewicz M., Hubicki Z.: Solvent Extr. Ion Exc., 2016, 34,

558. https://doi.org/10.1080/07366299.2016.1218694

[12] Konsowa A.: Desalination, 2003, 158, 233.

https://doi.org/10.1016/S0011-9164(03)00458-2

[13] Tsui L., Roy W., Cole M.: Color. Technol., 2003, 119, 14.

https://doi.org/10.1111/j.1478-4408.2003.tb00145.x

[14] Gupta V., Gupta B., Rastogi A. et al.: J. Hazard. Mater., 2011,

186, 891. https://doi.org/10.1016/j.jhazmat.2010.11.091

[15] Krowiak A., Szafran R., Modelski S.: Desalination, 2011, 265,

126. https://doi.org/10.1016/j.desal.2010.07.042

[16] Ofomaja A., Ho Y.: Dyes Pigments, 2007, 74, 60.

https://doi.org/10.1016/j.dyepig.2006.01.014

[17] Ho Y.., Chiu W., Wang C.: Bioresource Technol., 2007, 96,

1285. https://doi.org/10.1016/j.biortech.2004.10.021

[18] Wang X., Xia L., Tan K., Zheng W.: Environ. Prog. Sustain. Energy, 2012, 31, 566. https://doi.org/10.1002/ep.10582

[19] Chaparadza A., Hossenlopp J.: Water Sci. Technol., 2012, 65, 940. https://doi.org/10.2166/wst.2012.935

[20] Latif S., Rehman R., Imran M. et al.: J. Chem., 2019, 2019, 1. https://doi.org/10.1155/2019/6704953

[21] Nehaba S., Abdullah R., Oda A. et al.: Orient. J. Chem., 2019, 35, 1201. https://doi.org/10.13005/ojc/350341

[22] Ho Y., Chiang T., Hsueh Y. : Process Biochem., 2005, 40, 119. https://doi.org/10.1016/j.procbio.2003.11.035

[23] Santhi T., Manonmani S., Vasantha V., Chang Y.: Arabian J.

Chem., 2016, 9, S466. https://doi.org/10.1016/j.arabjc.2011.06.004
[24] Cheruiyot G., Maina E.: Sci. African, 2019, 5, 1.

https://doi.org/10.1016/j.sciaf.2019.e00116

[25] Sahmoune M., Ouazene N.: Environ. Prog. Sustain Energ., 2012, 31, 597. https://doi.org/10.1002/ep.10594

[26] Sun G., Xu X.: Ind. Eng. Chem. Res., 1997, 36, 808.

https://doi.org/10.1021/ie9603833

[27] Efanov M., Klepikov A.: Chem. Nat. Comp., 2001, 37, 80.

https://doi.org/10.1023/A:1017666913519

[28] Thinakaran N., Baskaralingam P., Pulikesi M. et al.: J. Hazard.

Mater., 2008, 151, 316. https://doi.org/10.1016/j.jhazmat.2007.05.076

[29] Farah J., EL-Gendy N., Farahat L.: J. Hazard. Mater., 2007, 148,

402. https://doi.org/10.1016/j.jhazmat.2007.02.053

[30] Aksu Z., Donmez D.: Chemosphere, 2003, 50, 1075.

https://doi.org/10.1016/S0045-6535(02)00623-9

[31] Suteu D., Zaharia C., Malutan T.: J. Serb. Chem. Soc., 2011, 76,

607. https://doi.org/10.2298/JSC100721051S

[32] Dakhil I.: J. Kerbala Univ., 2013, 11, 5.

[33] Subbaiah M., Vijaya Y., Subba R. et al.: Desalination, 2011, 276,

310. https://doi.org/10.1016/j.desal.2011.03.067

[34] Teka T., Enyew S.: Int. J. Innovat. Sci. Res., 2014, 8, 106.

Received: August 29, 2019 / Revised: December 09, 2019 / Accepted: May 02, 2020

\section{АДСОРБЩЯ КАТІОННИХ І АНІОННИХ БАРВНИКІВ 3 ВОДНОГО РОЗЧИНУ З ВИКОРИСТАННЯМ ЛУШПИННЯ СОНЯШНИКУ}

\begin{abstract}
Анотація. Досліджено вилучення катіонного (діамантовий зелений) та аніонного барвника (метилоранж) із стічних вод, з використанням як адсорбенту лушпиння соняшнику. Дослідження проводили серіями за різних концентрацій розчину барвника, кількостей адсорбенту, значень $\mathrm{pH}$, розмірів частинок та при різних значеннях часу контакту. Для обох барвників встановлено, щзо кількість видаленого барвника збільшується зі збільшенням часу та кількості адсорбенту $i$ зменшується зі збільшенням кониентрації барвника та розміром частинок. Час встановлення рівноваги змінювався залежно від умов досліджень. Визначено, що оптимальна ступінь видалення діамантового зеленого становить $98 \%$ за концентрачії барвника 50 ррт, кількості адсорбенту 2 гыл, розмірі частинок 75 мкм та рН 7 за час 1 год порівняно з $54 \%$ метилоранжу за оптимальних умов (концентрація барвника 10 ррт, кількість адсорбенту 4 г/л, рН 3 при однакових розмірах частинок і однаковому часі). Проведені кінетичні дослідження показали, щз адсорбиія визначається псевдомоделлю другого порядку і може бути описана ізотермою Лангмюра.
\end{abstract}

Ключові слова: адсорбиія, лушпиння соняшнику, метилоранж, діамантовий зелений, основні барвники, кислотні барвники. 